

$1916 \cdot 2021$

\title{
Integrated Environmental Management and Planning based on Soil Erosion Susceptibility Scenarios
}

\author{
ELENICE B. WEILER, MARÍLIA F. TAMIOSSO, JUSSARA C. CRUZ, JOSÉ MIGUEL \\ REICHERT, LUIS PAULO B. SCHORR, BRUNO C. MANTOVANELLI, FERNANDA D. \\ DOS SANTOS, ROBERTA A. FANTINEL \& EDNER BAUMHARDT
}

\begin{abstract}
This article presents the identification of soil use potential for different agropastoral and forest scenarios, using an indicator for erosion susceptibility from the spatialized Universal Soil Loss Equation (USLE). All USLE factors were spatialized using ArcGis 10.5 software, for the case study of the Cachoeira Cinco Veados Watershed-RS. To determine the $\mathrm{R}$ factor, we used the Cassol et al. 2007 equation and a 33-year series of rain data from six climatic stations. For the $\mathrm{K}$ factor, published values for the soil classes: Entisol, Ultisol, Oxisol, Molisols were used. From the DEM, the LS factor was obtained, considering six slope classes (0-3, 3-8, 8-20, 20-45, 45-75, >75\%). In addition to the actual land use situation in the watershed, nine scenarios were proposed for the $\mathrm{C}$ factor. The value of 0.5 was used for the evaluation of conservation practices ( $P$ factor). Considering scenarios of current use situation along with the nine other scenarios, the results showed that, by identifying the most susceptible areas in each scenario, it is possible to construct an indicator map of soil compatibilities for each use, considering sustainable limits of soil losses. Therefore, this resulting map has potential use as instrument for land use planning and zoning studies.
\end{abstract}

Key words: Environmental Planning, Modeling, USLE, Water Erosion.

\section{INTRODUCTION}

High rates of soil degradation harm agricultural and forest production (Mosbahi et al. 2013, Hu \& Flanagan 2013, Bonumá et al. 2014, Dyonisio 2010) and often have their cause linked to water erosion. Erosion by water is a natural cause (Silva et al 2010), which may be aggravated by the use of inadequate soil management techniques. Cândido et al. 2014 explain that soil cover and management system are important factors that influence the intensity of runoff and water erosion in forest systems.

The characteristics of the climate, relief, vegetation cover and soil type should be taken into account when planning the use of an area, regardless of the purpose, considering that the activities altering the soil surface structure, together with the inadequate management, make it prone to erosion (Bertoni \& Lombardi Neto 2010, De Araújo et al. 2009) and regulate its intensity (Costa et al. 2009). Sheet erosion is highly related to anthropic activity, considering the forms of soil occupation, where different areas may have the same susceptibility to erosion. However, for different uses, such areas will present different classes of potential erosion (Kreitlow et al. 2016). Considering the influence of anthropic activities, Didoné et al. 2014 observed that soil management systems 
used by farmers are inefficient to reduce runoff and erosion in cropping areas, evidencing the effects of cropping systems on soil losses.

For farming with a lower environmental impact, knowledge and planning are needed at different scales of analysis and in an integrated way. The study of soil erosion can anticipat knowledge can direct the human activity towards sustainable soil uses (Lopes et al. 2011, Minella et al. 2009, 2007).

Thus, soil loss potential by water erosion is among the variables to be considered in planning processes. The Universal Soil Loss Equation (USLE) is a methodology, among others, developed to consider this factor in planning, being the most used model in the world and in Brazil for erosion forecasting (Pham et al. 2018, Avanzi et al. 2013, Beskow et al. 2009) and to estimate the average annual soil loss rates for different soils and climatic conditions (Silva et al. 2016). The application of this model of soil loss estimation associated with GIS is a viable alternative for planning and improvement of the results, since it allows extrapolating information useful for land use planning through treatment, analysis and data modeling (Oliveira et al. 2015, Silva et al. 2013, Bonumá et al. 2013, Chou 2010), besides quantifying soil losses at different scales (Avanzi et al. 2013). The main reasons why USLEtype modeling is used worldwide are certainly its high degree of flexibility and accessibility to data, a parsimonious parameterization, and the extensive scientific literature (e.g. Avanzi et al. 2019, Schmidt et al. 2019, Weiler et al. 2019, Cassol et al. 2018, Silva et al. 2017, Schick et al. 2017, Tuchtenhagen et al. 2017, Ali \& Hagos 2016, Bagio et al. 2016, Medeiros et al. 2016, Zola \& Juvenal 2016, Graça et al. 2015, Braz et al. 2014, Volk \& Cogo 2014) and comparability of results, allowing the model to be adapted to almost all types of conditions and regions of the world (Alewell et al. 2019).
Finding strategies to reduce erosive processes is in agreement with the objectives of this study, since the use of this simple data processing tool has great potential for satisfactory results in the watershed level and it may contribute to the environmental planning focusing on soil loss prevention criteria. In this study, the application of spatialized USLE was chosen as a tool in planning, prevention and mitigation of soil loss because it is widely studied and discussed, as in the publications of Tesfaye et al. 2018, Silva et al. 2017, Durães \& Mello 2016, Lin et al. 2016, Coutinho et al. 2014, Pradhan et al. 2012, Souza \& Gasparetto 2012, Gurgel et al. 2011, Guimarães et al. 2011 and Stipp et al. 2011. Chatterjee et al. 2014 highlight that the classification of areas vulnerable to erosion using geospatial techniques is significant for watershed management and planning, and it may also be used for estimates in contiguous watershed of a region with similar landscape conditions.

The Cachoeira Cinco Veados watershed, in this case study, is affected by erosion, as many parts of the watershed have been in continuous development for more than four decades. The study region, although located in a mountainous area, is part of the Pampa Biome and its vegetation has undergone natural and anthropic changes over the years, largely due to the agricultural development and management techniques, and the introduction of new crops in areas previously characteristic of this biome (MMA 2016). Thus, the agricultural potential of a given region, associated with soil conservation practices integrated with spatial tools (Cerdà et al. 2016, Mekonnen et al. 2014), may provide evidence for a possible future forecast of the possible resulting impacts, as well as association with longer time series of data. In other words, the effectiveness of these practices may be improved if the spatialization 
of soil loss classes associated with the influence of cultivation practices is considered, instead of simple conditions, just inserting the current losses (Di Stefano \& Ferro 2016).

Removal of the natural biome that was performed in this watershed, with no repercussion on the environmental consequences, can be the key of the erosion problems in the watershed. In addition, the rapid increase in urbanization, such as the construction of unpaved roads (highways and local roads) and many agricultural activities are also very common in the area.

Considering erosion as one of the main causes of soil degradation in watersheds, this study aims to assess the dynamic and spatial risks of soil erosion by associating changes in land use. This is achieved using data officially available for the watershed scale and correlating the results of the soil loss forecast with different changes and occupation in the area.

\section{MATERIALS AND METHODS}

The study area, Cachoeira Cinco Veados Watershed (CCVW), is located in the Ibicuí River Watershed - Uruguay Hydrographic Region, in the extreme west of the state of Rio Grande do Sul, Brazil, between the geographic coordinates

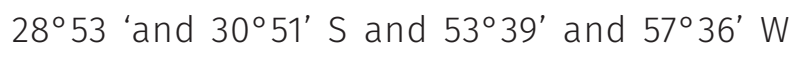
(Figure 1). It is located in the transition zone between the Central Depression and the Plateau Sul-Riograndense, covering the municipalities of Tupanciretã. Quevedos, Júlio de Castilhos and São Martinho da Serra, with a drainage area of $1541.9 \mathrm{~km}^{2}$ and emphasis on the Toropi and Guassupi Rivers.

\section{USLE model}

The calculation of the potential erosion of the watershed was based on the Universal Soil Loss Equation proposed by Wischmeier \& Smith 1978 (Equation 1), with the aid of a Geographic Information System, ArcGis 10.2.1 software, for spatialization factors.

A=R.K.LS.C.P

(1)

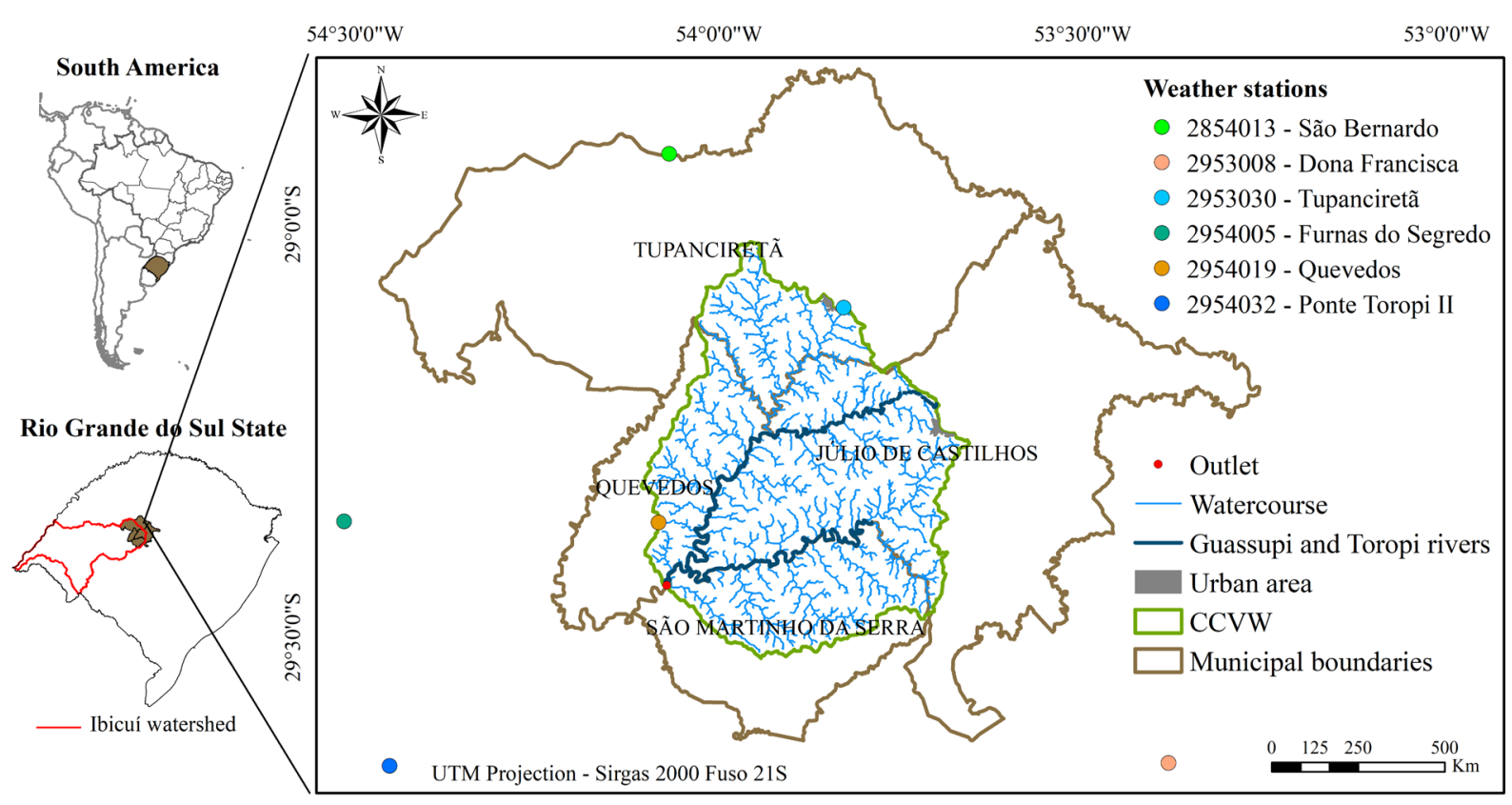

Figure 1. Location of the study area and weather stations. 
where: $A$ is the average annual soil loss (t.ha-1.year-1), $\mathrm{R}$ is the rainfall erosivity (MJ. $\left.\mathrm{mm} \cdot \mathrm{ha}^{-1} \cdot \mathrm{h}^{-1} \cdot \mathrm{year}^{-1}\right), \mathrm{K}$ is the soil erodibility factor (t.h. $\mathrm{MJ}^{-1} \cdot \mathrm{mm}^{-1}$ ), LS is the topographic factor (dimensionless), $\mathrm{C}$ is the cropping management factors (dimensionless), and $P$ is the practice support factor (dimensionless).

Next, it is presented how to apply each factor of the model. already presenting the data of the case study. However, for replication in another region, researchers must seek similar data from the region where the methodology will be applied.

In order to calculate the $\mathrm{R}$ factor, the data were obtained by the HidroWeb software of the National Water Agency (ANA 2016). They were obtained from six weather stations (Figure 1) from 1985 to 2015, with continuous data consisting of total annual rainfall and total monthly rainfall, being the rainfall erosivity $(R)$ calculated for each season from Equation 2 developed by Cassol et al. 2007 for the region of ljuí (RS).

$$
\Sigma R=R=109.65^{*}\left(p^{2} / P\right)^{0.76}
$$

where: $p=$ mean monthly rainfall $(\mathrm{mm})$; $P=$ mean annual rainfall $(\mathrm{mm}) ; \mathrm{R}=$ monthly average erosion index (MJ.mm.ha ${ }^{-1} \cdot h^{-1} \cdot$ month $\left.^{-1}\right)$; $\Sigma \mathrm{R}=$ rainfall erosivity $\left(\mathrm{MJ} \cdot \mathrm{mm} \cdot \mathrm{ha}^{-1} \cdot \mathrm{h}^{-1} \cdot \mathrm{ano}^{-1}\right)$. After calculating the $\mathrm{R}$, a raster map was created by means of the interpolation of the values of each station by the Inverse Distance Weigthed - IDW method.

The $\mathrm{K}$ values followed experimental works already developed by Durães \& Mello 2016, Pasquatto \& Tomazoni 2016, Didoné et al. 2015, Graça et al. 2015, Shabani et al. 2014, Franco et al. 2012, Costa et al. 2009 and Tomazoni et al. 2005.

During data processing, we used the soil classification map based on the survey map of the soils of Rio Grande do Sul - scale 1:750.000 (BRASIL 1973). The classes of Entisol ( $K=0.03280)$, Ultisol (Tuia K=0.02857; Júlio de Castilhos $\mathrm{K}=0.03119$ ), Oxisol (Cruz Alta $\mathrm{K}=0.02078$; Passo Fundo $K=0.02260$ ) and Molisols ( $K=0.04540)$, with an area of $738.06 \mathrm{~km}^{2}, 464.49 \mathrm{~km}^{2}, 324.67 \mathrm{~km}^{2}$ and $13.8 \mathrm{~km}^{2}$, respectively. Then a raster was created for factor K (Figure 2).

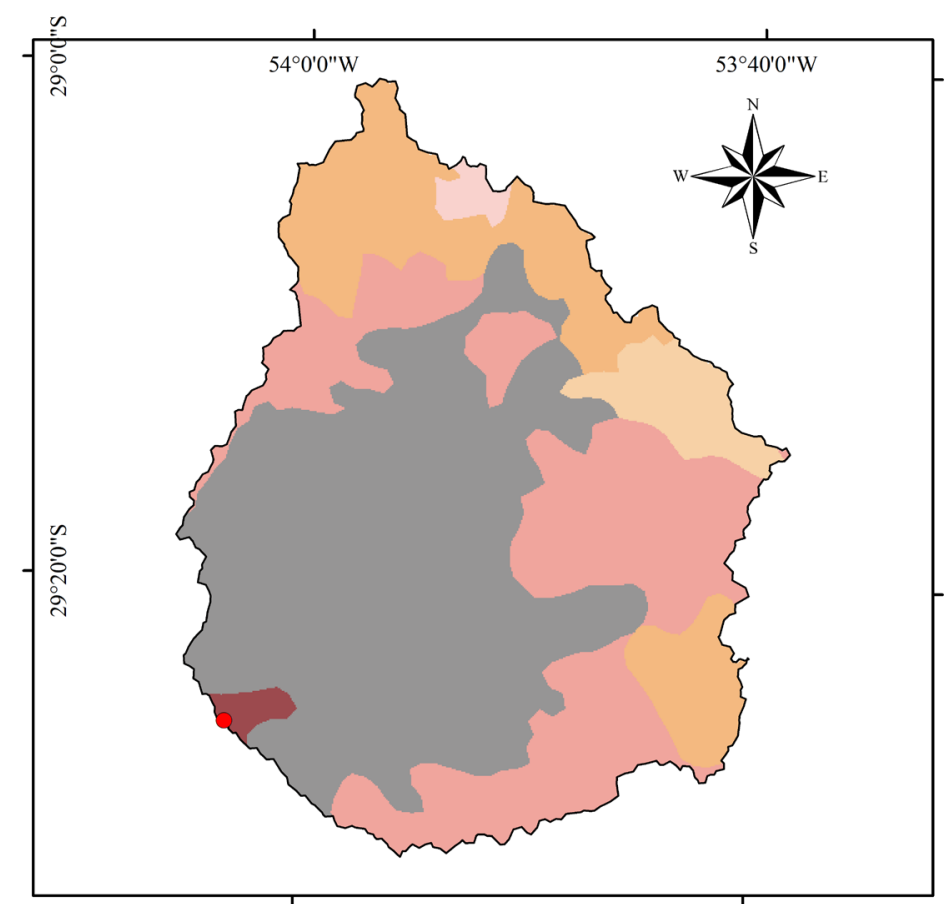

\section{Soil Erodibility - K Factor}

(t.h.Mj-' ${ }^{\mathbf{1}} \cdot \mathbf{m m} \mathbf{-}^{\mathbf{1}}$ )

0.02078 - U.M. Cruz Alta

0.02260 - U.M. Passo Fundo

0.02857 - U.M. Tuia

0.03119 - U.M. Júlio de Castilhos

0.03280 - U.M. Guassupi

0.04540 - U.M. Ciríaco-Charrua

CCVW

- Outlet

UTM Projectiom - Sirgas 2000 Fuso 21S

Figure 2. Soil Erodibility Factor Map (K).

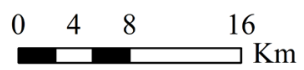


The Digital Elevation Model (DEM) of SRTM in the GEOTIFF, $30 \mathrm{~m}$ resolution, format was obtained from the Laboratory of Geoprocessing of the Ecology Center of the Federal University of Rio Grande do Sul - UFRGS, adapted to the state of Rio Grande do Sul by Weber et al. 2016. From the DEM, a methodological procedure was performed based on Moore \& Burch 1986 and Desmet \& Govers 1996 to obtain the raster of the LS factor for the watershed. The six declivity classes considered for this study were (0-3, 3-8, 8-20, 20-45, 45-75 and greater than 75\%) (Santos et al. 2013). The first three classes of slope stand out with $99 \%$ of the area, presenting flat to undulating relief, but there are well-marked areas such as rock walls, hills and waterfalls.

The $C$ values were obtained from the literature, including Barbosa et al. 2015, Didoné et al. 2015, Martins et al. 2010, Galdino et al. 2004 and Wischmeier \& Smith 1978. The actual soil use in the watershed was obtained from the database of the MMA 2016: $65.02 \%$ of the area with farming use. C value varies according to crop (soybean - 0.0155, oat - 0.02083, corn $0.01155), 31.54 \%$ of the area with natural field use $(C=0.08285)$, and the remaining $3.45 \%$ with native forest $(C=0.00942)$, reforestation $(C=$ $0.03270)$, urban anthropic $(C=0.036722)$ and water $(C=0)$. In addition to the actual land use situation in the watershed, a further 9 scenarios were elaborated for the $\mathrm{C}$ factor. Then, a raster was created for each scenario of $\mathrm{C}$ factor.

The value of 0.5 was used for the evaluation of conservation practices for arable areas, referring to the practice of planting around the region, a value referenced by Bertoni \& Lombardi Neto 2010.

\section{Studied scenarios}

The suggested scenarios are as follows: a) USLE, where factor $C$ is the current use of the area and the agricultural sector assumes the value as soybean/pasture/soybean $(C=0.0155)$. In the other scenarios, factor $\mathrm{C}$ was varied with different managements: b) USLE01, where the agricultural value assumes the value of factor $\mathrm{C}$ as soybean / fallow/oat agriculture ( $C=0.02083$ ); c) USLE02, where the agricultural value assumes the value in factor $\mathrm{C}$ as soybean/bare soil/soybean ( $\mathrm{C}=$ 0.10273); d) USLE03, where the agricultural value assumes the value in factor $C$ as soybean/ oat/corn ( $C=0.01155$ ); and e) USLE04, the agricultural sector assumes the value of factor $C$ ( $C=0.03382$ ), representing cattle raising activity. Scenarios were created with a single type of soil use, respecting urban areas and with water: $f$ ) USLE05, with simulation of entire watershed with agricultural use soybean/pasture/soybean; g) USLE06, with cattle raising; h) USLE07, with reforestation; i) USLE08, with native forest; and j) USLE09, for natural field use.

The erosive values were categorized according to the methodology of Ribeiro 2006, where $1<A=$ very low, $1 \leq A<10=$ low, $10 \leq A<50=$ low to moderated, $50 \leq A<100=$ moderate, $100 \leq A<$ $500=$ moderate to high, $500 A<1.000=$ high, 1.000 $A<5.000=$ very high and $A>5.000=$ extreme.

\section{RESULTS}

For the current land use scenario (USLE), the watershed presents $8.43 \%$ of total potential losses considered in the very low class (0-1 t.ha ${ }^{-}$ ${ }^{1}$.year ${ }^{-1}$ ) in the slope areas between 0-3 \% (low fragility and flat relief), occupying around 10\% of the total area of the watershed. These areas are spatialized in all types of soil present in the watershed. with resistance varying from very low to high. Less than $5 \%$ of the watershed has areas with high erosion (500-1.000 t.ha ${ }^{-1}$.year ${ }^{-1}$ ) spatially distributed in the southern region of the watershed, in hilly relief to mountainous. 
distributed in all declivity classes except $>75 \%$, and they are in all types of soil and uses.

In the soil loss maps by different covers in the same area. we have the comparison of potential erosion as a function of different agricultural scenarios (USLE, USLE01, USLE02, USLE03) and cattle raising activity (USLE04) (Figure 3). The scenarios: soybean/pasture soybean, soybean/ oat/maize and soybean/fallow/oat showed similar average potential losses, in the range of 35 to $45 \mathrm{t}^{\text {tha }}{ }^{-1}$.year ${ }^{-1}$. The soil use with cattle raising approximate these values, but with a higher potential erosion, between 45-55 t.ha-1. year $^{-1}$. On the other hand, the soybean/bare soil / soybean scenario distances itself from the behavior of the other scenarios, presenting a high potential loss (> 85 t.ha $^{-1} \cdot$ year $^{-1}$ ).
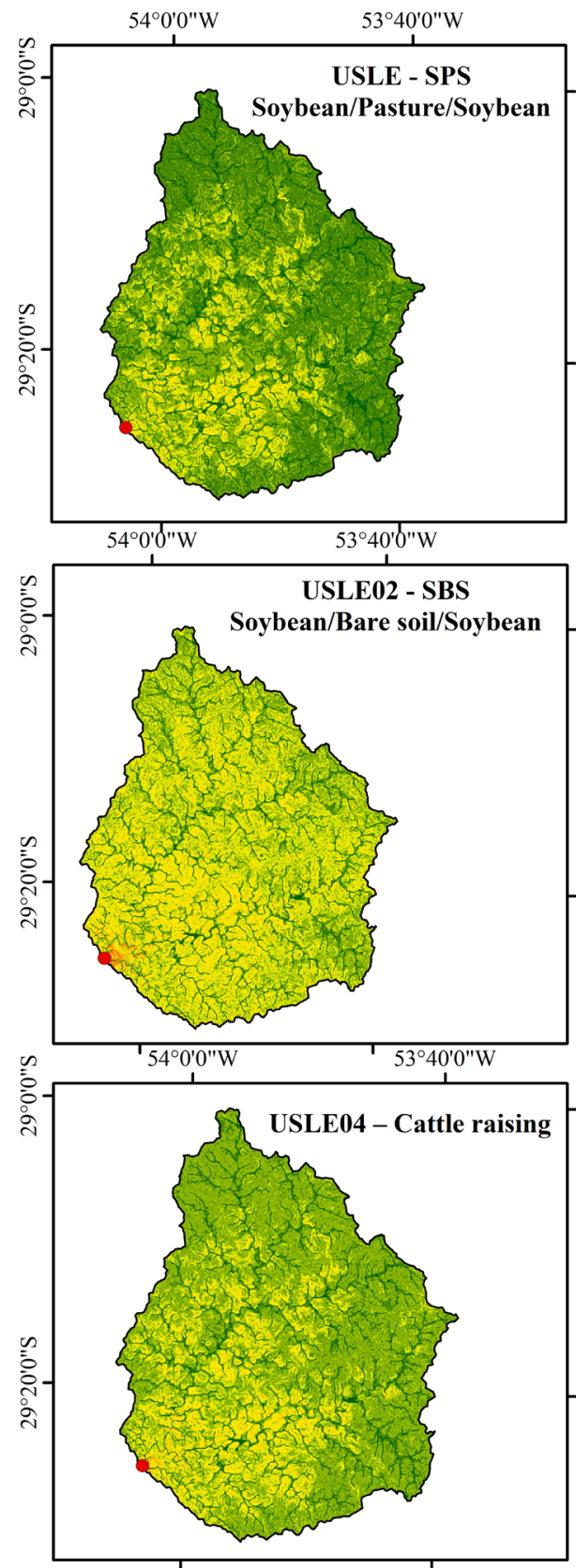
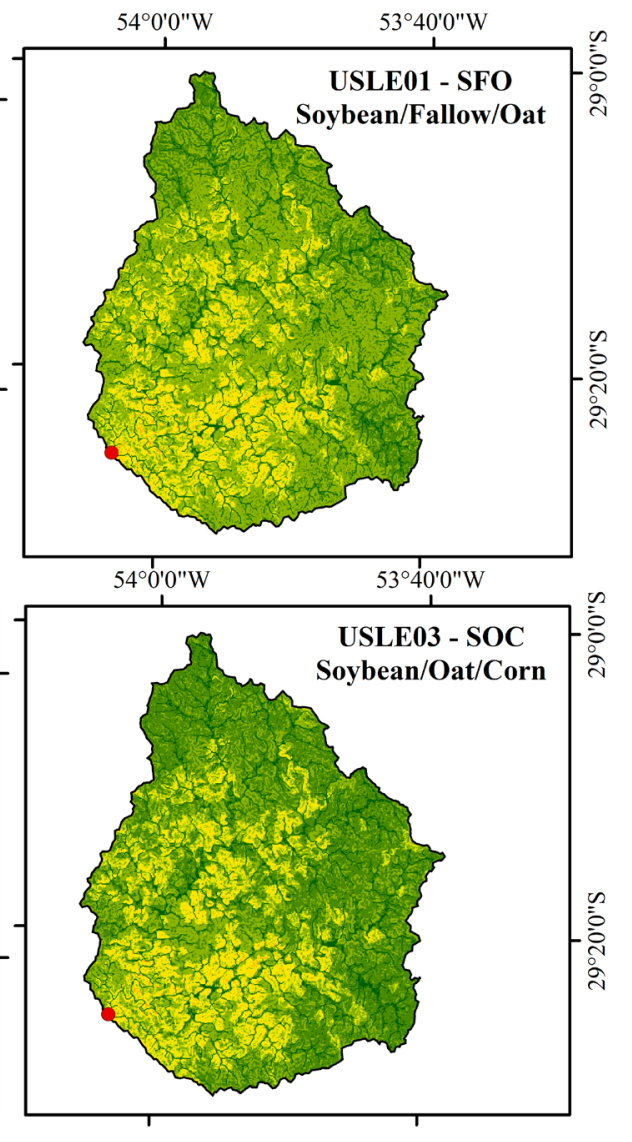

Predicted Soil Erosion

(t.ha-' .ano- $\left.^{1}\right)$

$0-1$

$1-10$

$10-50$

$\square 50-100$

$\square 100-500$

$500-1.000$

$1.000-5.000$

$>5.000$
Figure 3. Distribution of predicted soil erosion according to the criterion of Ribeiro (2006) for different soil uses. 
For each scenario, there is a distribution of total predicted soil erosion in the watershed as a function of the classes of predicted soil erosion, as well as of areas contemplated in each class of predicted soil erosion (Figure 4). The highest percentage of area remained in the class of 1050 t.ha $^{-1}$.year ${ }^{-1}$ for the soybean/pasture/soybean, soybean/fallow/oat and cattle raising scenarios; however, this represents about 7\% of the total predicted soil erosion.

The soybean/oat/maize scenario presented a higher percentage of area in the class considered as low erosive potential (1-10 t.ha${ }^{1}$.ano ${ }^{-1}$ ), approximately $50 \%$ of the watershed area with potential up to 10 t.ha $^{-1}$.year ${ }^{-1}$. Notwithstanding, about $75 \%$ of total potential losses are concentrated in the highest ranges of

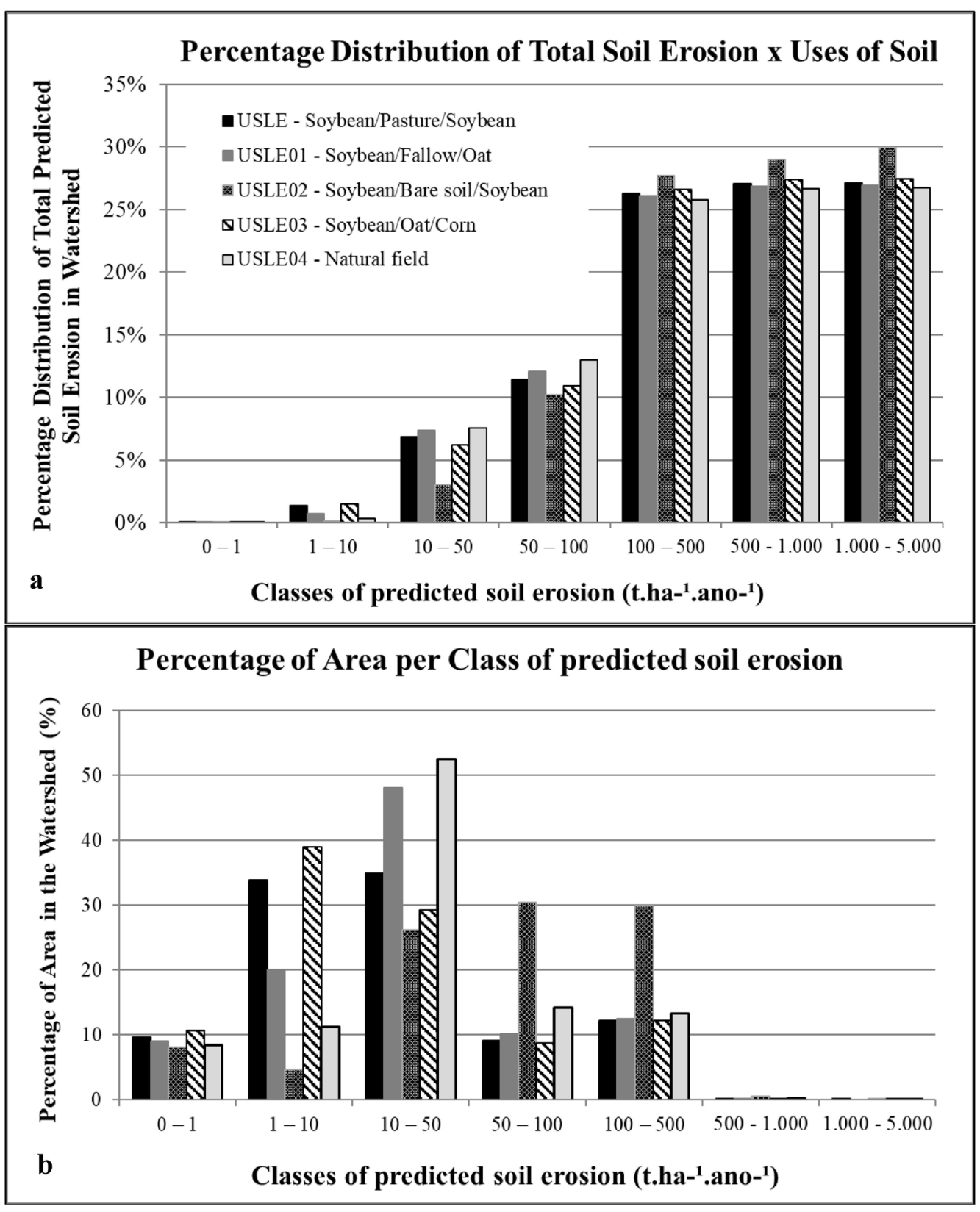

Figure 4. Different land use scenarios: (a) Percentage distribution of total soil erosion; (b) Percentage of area per predicted class of soil erosion. 
predicted soil erosion (100-5000 tha thear $^{-1}$ ), the remaining $50 \%$.

The soil use scenario for agriculture in the soybean/bare soil/soybean system was more prone to erosion, with $85 \%$ of the watershed areas concentrated in the potential loss classes (10-500 t.ha- ${ }^{-1}$.year ${ }^{-1}$ ), and with percentages of total potential loss in the highest potential erosion classes of (100-5.000 t.ha ${ }^{-1}$.year ${ }^{-1}$ ).

When analyzing soil use with cattle raising, it is possible to observe a smaller number of areas in the classes considered less susceptible to erosion compared to the scenarios with agriculture, except for scenario USLE04 (soybean/bare soil/soybean). In some classes this difference between cattle raising and agriculture exceeds $40 \%$ of the total area of this watershed.

To verify changes of areas in the watershed and the influence that each soil use reflects on soil loss rates, some scenarios were proposed. Besides wetlands and urban areas, the watershed presents the following soil uses scenarios: agriculture - soybean/pasture/ soybean (USLE05), cattle raising (USLE06), reforestation (USLE07), native forest (USLE08) and natural field (USLE09) (Figure 5).

In relation to predicted soil erosion, there was little change of area between the scenarios and the current scenario, except for that

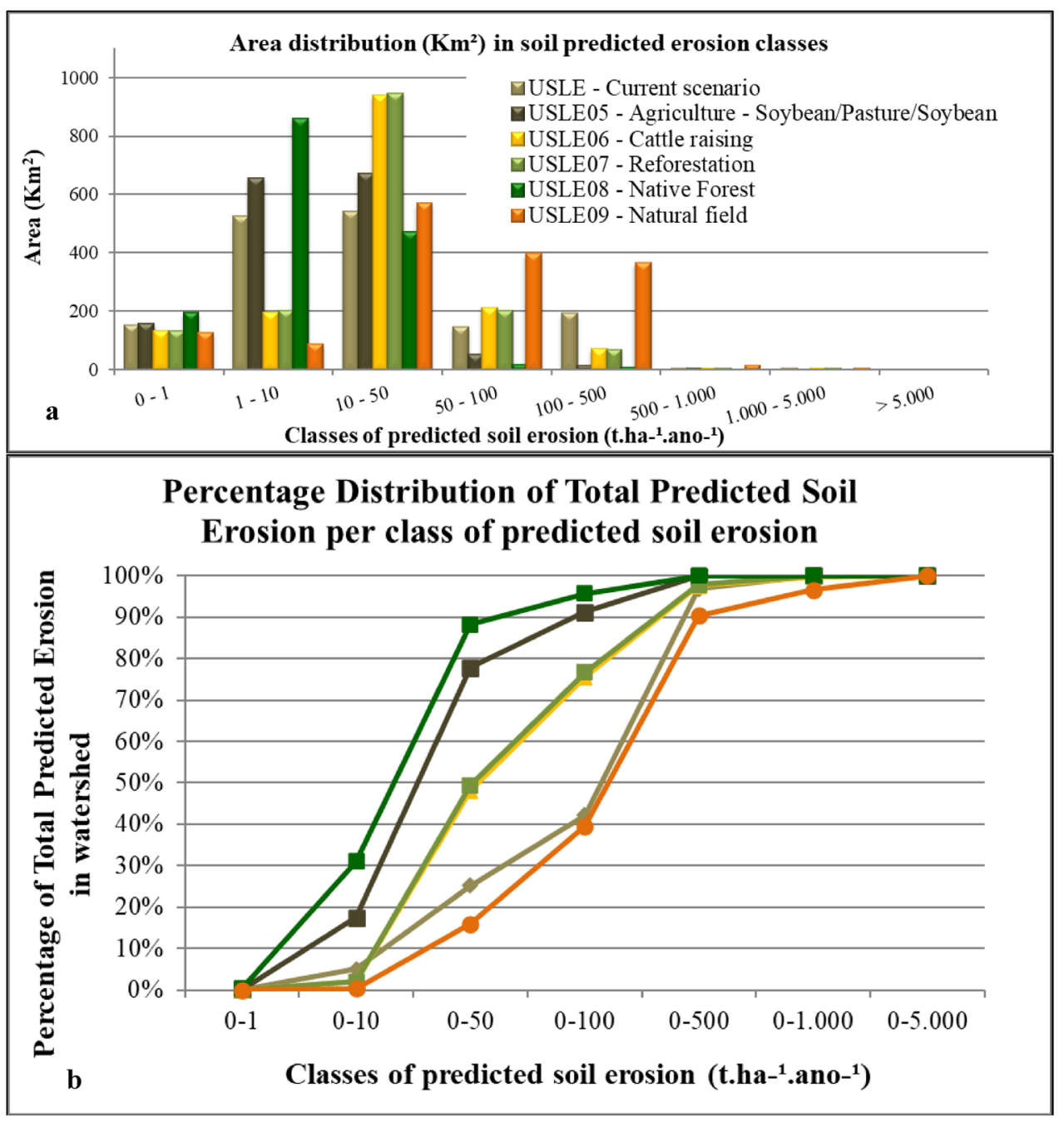

Figure 5. Soil use scenarios: (a) Area distribution $\left(\mathrm{km}^{2}\right)$ in soil loss classes; (b) Percentage distribution of total predicted soil erosion per class of predicted soil erosion. 
modified for natural field use. The native forest scenario (USLE08) had the largest area (1521.73 $\left.\mathrm{km}^{2}\right)$ present in the class least susceptible to erosion (0-50 t.ha $a^{-1}$.year $\left.{ }^{-1}\right)$, followed by agriculture (soybean/pasture/soybean). Being 2.68\% greater than the area of these same classes in relation to the scenario USLE05, and $17 \%$ in relation to the scenario used for cattle raising (USLE06).

The cattle raising scenario and the reforestation scenario are similar in area by classes, presenting similar responses in the erosive behavior. Nevertheless, there was migration of areas for the classes of 50-100 tha ${ }^{1}$.year ${ }^{-1}$ presenting a more susceptible character than with current use. All in all, the result that differs from the current scenario is the natural field, where the areas with losses are larger.

Table I presents comparative percentage values of the watershed areas in the classes of predicted soil erosion for each soil use scenario in relation to the current use. The first column expressed the classes of predicted soil erosion. The second column represents the current use scenario of the watershed soil with the areas framed by predicted soil erosion class $\left(1^{\text {st }}\right.$ column). The other columns present titration for the evaluated use, and are divided in two columns, the first with the areas framed in each class of predicted soil erosion and the second, with percentage variation of area compared to the current use scenario ( $2^{\text {nd }}$ column).

Negative values represent migration of areas from one class to another. In contrast to the current scenario, each use presents a greater or smaller variation of area per class of predicted soil erosion. We can highlight here the native forest scenario, which presents an increase of about $25 \%$ of the area for the classes of smaller susceptibility to erosion.

\section{DISCUSSION}

The analysis based on the mean and total potential losses and the relation with the watershed area allows the manager to analyze susceptible classes to the erosive processes, the classes which deserving more attention in the

Table I. Percentage variation of areas of the soybean/pasture/soybean (USLE05), cattle raising (USLE06), reforestation (USLE07), native forest (USLE08) and natural field (USLE09) scenarios compared to the current scenario (USLE).

\begin{tabular}{|c|c|c|c|c|c|c|c|c|c|c|c|}
\hline \multirow{2}{*}{$\begin{array}{c}\text { Classes } \\
\left(\text { t.ha } a^{-1} \cdot \text { ano }^{-1}\right)\end{array}$} & \multirow{2}{*}{$\begin{array}{c}\begin{array}{c}\text { Current } \\
\text { scenario }\end{array} \\
\begin{array}{c}\text { Area } \\
\left(\mathrm{Km}^{2}\right)\end{array}\end{array}$} & \multicolumn{2}{|c|}{$\begin{array}{c}\text { Agriculture - } \\
\text { Soybean/Pasture/ } \\
\text { Soybean }\end{array}$} & \multicolumn{2}{|c|}{ Cattle raising } & \multicolumn{2}{|c|}{ Reforestation } & \multicolumn{2}{|c|}{ Native Forest } & \multicolumn{2}{|c|}{ Natural field } \\
\hline & & $\begin{array}{c}\text { Area } \\
\left(\mathrm{Km}^{2}\right)\end{array}$ & Variation & $\begin{array}{c}\text { Area } \\
\left(\mathrm{Km}^{2}\right)\end{array}$ & Variation & $\begin{array}{l}\text { Area } \\
\left(\mathrm{Km}^{2}\right)\end{array}$ & Variation & $\begin{array}{l}\text { Area } \\
\left(\mathrm{Km}^{2}\right)\end{array}$ & Variation & $\begin{array}{l}\text { Area } \\
\left(\mathrm{Km}^{2}\right)\end{array}$ & Variation \\
\hline $0-1$ & 148.9 & 153.9 & $0.3 \%$ & 130.0 & $-1.2 \%$ & 130.3 & $-1.2 \%$ & 192.7 & $2.8 \%$ & 123.8 & $-1.6 \%$ \\
\hline $1-10$ & 522.1 & 656.6 & $8.7 \%$ & 194.4 & $-21.3 \%$ & 198.4 & $-20.9 \%$ & 859.5 & $21.9 \%$ & 83.8 & $-28.4 \%$ \\
\hline $10-50$ & 538.2 & 670.4 & $8.6 \%$ & 937.8 & $25.9 \%$ & 946.2 & $26.5 \%$ & 469.6 & $-4.5 \%$ & 564.6 & $1.7 \%$ \\
\hline $50-100$ & 140.9 & 48.4 & $-6.0 \%$ & 207.5 & $4.3 \%$ & 200.7 & $3.9 \%$ & 15.9 & $-8.1 \%$ & 392.6 & $16.3 \%$ \\
\hline $100-500$ & 188.7 & 12.5 & $-11.4 \%$ & 70.4 & $-7.7 \%$ & 64.8 & $-8.0 \%$ & 4.3 & $-11.9 \%$ & 362.8 & $11.3 \%$ \\
\hline $500-1.000$ & 3.1 & 0.04 & $-0.2 \%$ & 1.6 & $-0.1 \%$ & 1.6 & $-0.1 \%$ & 0 & $-0.2 \%$ & 11.3 & $0.5 \%$ \\
\hline $1.000-5.000$ & 0.1 & 0 & $0.0 \%$ & 0.1 & $0.0 \%$ & 0.1 & $0.0 \%$ & 0 & $0.0 \%$ & 3 & $0.1 \%$ \\
\hline$>5.000$ & 0.0 & 0 & $0.0 \%$ & 0 & $0.0 \%$ & 0 & $0.0 \%$ & 0 & $0.0 \%$ & 0 & $0.0 \%$ \\
\hline Total & 1541.9 & 1541.9 & - & 1541.9 & - & 1541.9 & - & 1541.9 & - & 1541.9 & - \\
\hline
\end{tabular}


management. Even though the results show few areas in the higher classes of soil loss, these present the highest values of total potential losses. In the current soil use scenario (USLE), this characteristic is evident, in which only $12 \%$ of the watershed area is responsible for $60 \%$ of the total losses in the moderate-high class, needing priority attention.

The areas with high potential erosivity occur mainly in the transition places from Plateu to Central Depression of the state, where there are high slopes, hills, and even occurrence of waterfalls. The relief was also cited by Guimarães et al. 2019, in which areas of higher slope had the highest loss values, which contributed to the formation of particle drag in the runoff. Leomo et al. 2016 also found higher soil losses values due to shrubby soil use associated with slopes of $15 \%$ to $25 \%$ in a river watershed in Indonesia, reaching values up to 830.89 t.ha $^{-1}$.year ${ }^{-1}$.

In addition, the loss increases its potential when associated with fragile or overused soils. In this watershed. approximately $50 \%$ of its area is covered by Entisol, whose erosion resistance class is considered very low, and when associated with annual crops, presents high potentiality to erosive processes. Similar fact is described by Braga et al. 2017, in which the areas that were classified as high potential fragility are located in this type of soil. Galdino et al. 2004 applied the Universal Soil Loss Equation and they found similar values (555.6 t.ha $^{-1}$.year ${ }^{-1}$ ) to these of the Cachoeira Cinco Veados Watershed, in the Alto Taquari watershed. In these areas, the factor that contributes to high soil loss results refers to the inadequate soil use associated with soil type combined with slope. Similarly, the study by Durães \& Mello 2016 points to higher soil losses in rugged landscape, emphasizing the importance of maps in the identification and analysis of risk areas to erosion, providing subsidies for soil planning and conservation measures.

In the scenarios with different soil coverages (Figures 3 and 4), there are values considered with very high erosive potential, explained by the fact that the areas are related to factors such as high slopes and low to very low soil depth, following the logic explained by Campos et al. 2008. In agreement with the studies developed by Irvem et al. 2007, high values of precipitation regulate soil denudation and topographic variables are secondary but equally important to explain the process, confirming the different results found in the erosion estimation.

The mean values of predicted soil erosion found for scenarios USLE, USLE01 and USLE03 did not show significant variation due to the similar protection realized by crops in the area. On the other hand, the scenario that has bare soil during part of the time (USLE02) enhances losses, largely due to the susceptibility to these areas present during rainfall events. Silva \& Machado 2014 reinforce this idea when describing that areas without plant protection present more compacted soils and more susceptible to erosion processes.

In general terms, soil under cattle raising (USLE04) was more degradable than under annual crops, much due to cattle trampling, which favors soil compaction, thus reducing infiltration and favoring runoff. These are impacts also cited by Greenwood \& McKenzie 2001. Considering that the difference in average values is low, the identification of these areas and the correct management of cattle raising activity may be potential in soil use planning. For instance. the introduction of more diversified systems, such as crop-cattle raising integration, is important for the increase in soil organic matter (MOS) and provide well-structured soils, as cited by Franzluebbers 2007. In addition, Zolin et al. 2011 verified the significant reductions of soil loss 
in scenarios with conserved pasture, indicating that the optimization of soil conservation can be done by adopting conservationist management practices.

In terms of vegetation, soil protection varies depending on the type and the density of the cover. By analyzing the use and coverage factor through the USLE, it is possible to analyze the watershed in its current state of use, and to rethink the areas that should be relocated to cover the soil, due to predicted soil erosion in the higher classes, mainly in the southwest, a region near the exudation. The great advantage of the GIS-allied model is that it allows identification of the watershed areas that concentrate the highest values of predicted soil erosion. Considering each type of use individually, we may analyze the classification of these areas into classes of predicted soil erosion, as well as to quantify and to distribute potential mean and total soil losses in the watershed at intervals of class of predicted soil erosion.

The total area resulting from the variation between the scenarios, when classified in the soil loss classes, makes it possible to verify the spatial influence of the soil use in relation to soil loss susceptibility and to compare this scenario with other uses (Table I).

From the formulation of different soil uses it was possible to identify the behavior of watershed areas that presented high potential losses in the current scenario and that started to present lower values and less susceptible to erosion when they were altered. The advantage of this method of analysis lies in the fact that, as a combination of soils, slopes and erosivity in the watershed, it is possible to observe that the changes in the soil use scenarios are not linear.

The natural field scenario (USLE09) presented areas more susceptible to predicted soil erosion compared to native forest (USLE08), still showing the highest percentage of total predicted soil erosion in this watershed. This result is explained by the fact that the natural field vegetation is sparser and smaller in relation to the tree vegetation, since according to Martins et al. 2010, Alarcon et al. 2015 native forest allows the production of a large layer of litter, which provides protection to the soil. Silva \& Machado 2014 mention that forest areas create dense vegetation cover, which protects the soil from the effects of rainfall, thus contributing to slower infiltration and avoiding the accelerated and intense runoff. Silva et al. 2011 also described the decrease of potential erosion when introducing permanent preservation areas in their study.

The reforestation (USLE07) presented potential losses greater than those of the native forest (USLE08), as verified by Rodrigues et al. 2014 and Martins et al. 2010. However, this practice presents a satisfactory degree of coverage, since the tendency is to reduce soil losses in the area over time, because the plantations increase the canopy cover, consequently, the accumulation of litter (Oliveira et al. 2013), protecting the soil from rain drops and reducing their effects.

In the comparison between Eucalyptus stands and grass species. Reichert et al. 2017 observed that the watershed with forest stands, presented higher evapotranspiration, greater interception of rainfall and lower flow. Therefore, the cultivation of Eucalyptus can provide better structural conditions to the soil, greater infiltration and retention of water, and greater underground recharge, consequently it provides the reduction of soil degradation by erosion.

\section{CONCLUSION}

In order to obtain subsidies for integrated environmental planning and management. based on susceptibility to soil erosion. this study considered the spatial and dynamic 
analysis as a function of changes in land use for the watershed.

Depending on the adopted management (changes in the land use and cover scenario), changes in the erosive behavior were noticed. This information becomes relevant to managers, as in some scenarios high rates of soil loss are concentrated in few areas of the watershed.

The expected amount of soil loss and its spatial distribution provide a key information for comprehensive management and sustainable use of land for this watershed. For example, the need to avoid management activities where soil is exposed or to change the current use.

An understanding of the dynamics of erosion requires accurate information. However, little information is available on the factors responsible for susceptibility to soil erosion, which requires more specific studies in this topic. Finally, it is recommended studies aimed at the elaboration of a spatial database on soil properties, land use and vegetation.

\section{Acknowledgments}

For the financial support of the Coordenação de Aperfeiçoamento de Pessoal de Nivel Superior - Brazil (CAPES), Finance code 001.

\section{REFERENCES}

ALARCON GG, AYANU Y, FANTINI AC, FARLEY J, SCHMITT FILHO A \& KOELLNER T. 2015. Weakening the Brazilian legislation for forest conservation has severe impacts for ecosystem services in the Atlantic Southern Forest. Land Use Policy 47: 1-11.

ALEWELL C, BORRELLI P, MEUSBURGER K \& PANAGOS P. 2019. Using the USLE: Chances, challenges and limitations of soil erosion modelling. Int Soil Water Conserv Res 7: 203-225.

ALI AS \& HAGOS H. 2016. Estimation of soil erosion using USLE and GIS in Awassa Catchment, Rift valley, Central Ethiopia. Geoderma Reg 7: 159-166.
ANA - AGÊNCIA NACIONAL dE ÁGUAS. 2016. Hidro Web: Sistema de Informações Hidrológicas. Brasília-DF. http://hidroweb.ana.gov.br/.

AVANZI JC, SILVA MLN, CURI N, NORTON LD, BESKOW S \& MARTINS SG. 2013. Spatial distribution of water erosion risk in a watershed with Eucalyptus and Atlantic Forest. Ciênc Agrotec 37: 427-434.

AVANZI JC, VIOLA MR, MELLO CR, GIONGO MV \& PONTES LM. 2019. Modeling of the rainfall and R-factor for Tocantins state, Brazil. Rev Bras Cienc 43: 1-14.

BAGIO B, BERTOL I, WOLSCHICK NH, SCHNEIDERS D \& DOS SANTOS MAN. 2016. Water erosion in different slope lengths on bare soil. Rev Bras Cienc Solo 41: 1-15.

BARBOSA AF, OLIVEIRA EFD, MIOTO CL \& FILHO ACP. 2015. The Application of the Universal Soil Loss Equation by Using Free and Available Softwares. IGEO 38: 170-179.

BERTONI J \& LOMBARDI NETO F. 2010. Conservação do Solo. 7a ed., São Paulo: İcone, 355 p.

BESKOW S, MELLO CR, NORTON LD, CURI N, VIOLA MR \& AVANZI JC. 2009. Soil erosion prediction in the Grande River Basin, Brazil, using distributed modeling. Catena 79: 49-59.

BONUMÁ NB, ROSSI CG, ARNOLD JG, REICHERT JM, MINELLA JP, ALLEN PM \& VOLK M. 2014. Simulating Landscape Sediment Transport Capacity by Using a Modified SWAT Model. J Environ Qual 43: 55-66.

BONUMÁ NB, ROSSI CG, ARNOLD JG, REICHERT JM \& PAIVA EMCD. 2013. Hydrology Evaluation of the soil and Water assessment tool considering measurement uncertainty for a small watershed in Southern Brazil. Appl Eng Agric 29: 189-200.

BRAGA CC, CABRAL JBP, LOPES SMF \& BATISTA DF. 2017. Mapeamento da fragilidade ambiental na bacia hidrográfica do reservatório da UHE Caçu-Goiás. Ciênc Nat 39: 81-98.

BRASIL. 1973. Levantamento do reconhecimento dos solos do Rio Grande do Sul. Ministério da Agricultura/ Divisão de Pesquisas Pedológicas, Recife, 431 p. (Boletim Técnico 30).

BRAZ AM, SANTOS KPMG \& JULIO VA. 2014. Uso do geoprocessamento para avaliação da susceptibilidade erosiva da bacia hidrográfica do Córrego Ypê-Ilha Solteira/SP. Fórum Ambiental da Alta Paulista 10: 90-102.

CAMPOS MCC, MARQUES JÚNIOR J, MARTINS FILHO MV, PEREIRA GT, SOUZA ZM \& BARBIERI DM. 2008. Variação espacial da perda de solo por erosão em diferentes superfícies geomórficas. Cienc Rural 38(9): 2485-2492. 
CÂNDIDO BM, SILVA MLN, CURI N \& BATISTA PVG. 2014. Erosão Hídrica Pós-Plantio em Florestas de Eucalipto na Bacia do Rio Paraná, no Leste do Mato Grosso do Sul. Rev Bras Cienc Solo 38: 1565-1575.

CASSOL EA, MARTINS D, ELTZ FLF, LIMA VS \& BUENO AC. 2007. Esosividade e padrões hidrológicos das chuvas de ljuí (RS) no período de 1963 a 1933. Rev Bras Agrometeorol 15: 220-231.

CASSOL EA, SILVA TS, ELTZ FLF \& LEVIEN R. 2018. Soil erodibility under natural rainfall conditions as the $\mathrm{K}$ factor of the Universal Soil Loss Equation and application of the nomograph for a subtropical Ultisol. Rev Bras Cienc Solo 42: $1-12$.

CERDÀ A ET AL. 2016. The use of barley straw residues to avoid high erosion and runoff rates on persimmon plantations in Eastern Spain under low frequency-high magnitude simulated rainfall events. Soil Res 54: 154-165.

CHATTERJEE S, KRISHNA AP \& SHARMA AP. 2014. Geospatial assessment of soil erosion vulnerability at watershed level in some sections of the Upper Subarnarekha river basin, Jharkhand, India. Environ Earth Sci 71: 357-374.

CHOU W-C. 2010. Modelling Watershed Scale Soil Loss Prediction and Sediment Yield Estimation. Water Resour Manag 24: 2075-2090.

COSTA FHS, DE SOUZA FILHO CR \& RISSO A. 2009. Modelagem espaço-temporal da erosão e potencial contaminação de Arsênio e Chumbo na bacia hidrográfica do rio Ribeira de Iguape (SP). Rev Bras Geocienc 39: 338-349.

COUTINHO LM, CECÍLIO RA, GARCIA GO, XAVIER AC, ZANETTI SS \& MOREIRA MC. 2014. Calculating the LS factor of Universal Soil Loss Equation (USLE) for the watershed of River Silver, Castelo-ES. Revista Agro@mbiente On-line 8: 01-09.

DE ARAÚJO LE, SOUSA FDAS, NETO JMM, SOUTO JS \& REINALDO LRLR. 2009. Bacias hidrográficas e impactos ambientais. Qualit@s 8: 1-18.

DESMET PJ \& GOVERS G. 1996. A GIS procedure for automatically calculating the USLE LS factor on topographically complex landscape units. J Soil and Water Cons 51: 427-433.

DI STEFANO C \& FERRO V. 2016. Establishing a soil loss tolerance: an overview. J Agric Eng Res 47: 127-133.

DIDONÉ EJ, MINELLA JPG \& MERTEN GH. 2015. Quantifying soil erosion and sediment yield in a catchment in southern Brazil and implications for land conservation. J Soils Sediments 15: 2334-2346.
DIDONÉ EJ, MINELLA JPG, REICHERT JM, MERTEN GH, DALBIANCO L, BARRROS CAP \& RAMON R. 2014. Impact of no-tillage agricultural systems on sediment yield in two large catchments in Southern Brazil. J Soils Sediments 14: 1287-1297.

DURÃES MF \& MELLO CR. 2016. Spatial distribution of the potential and current soil erosion for the Sapucaí River Basin, MG, Brazil. Eng Sanit Ambient 21: 677-685.

DYONISIO HAF. 2010. Erosão Hídrica: Suscetibilidade do Solo. Rev Tesis 13: 15-25.

FRANCO ÂMP, CASSOL EA, PAULETTO EA \& INDA AV. 2012. Erodibilidade do Solo em entressulcos determinada experimentalmente e por Modelos Matemáticos em um Argissolo Vermelho. R Bras Agrociência 18: 175-187.

FRANZLUEBBERS AJ. 2007. Integrated crop-livestock systems in the southeastern USA. Agron J 99: 361-372.

GALDINO S, VIEIRA LM, PADOVANI CR, SORIANO BMA, RISSO A \& MELO EC. 2004. Erosão potencial laminar hídrica na bacia do alto Taquari. Rev Bras Recur Hidr 9: 125-133.

GRAÇA CH, PASSIG FH, KELNIAR AR, PIZA MA, CARVALHO KQ \& ARANTES EJ. 2015. Multitemporal analysis of estimated soil loss for the river Mourão watershed, Paraná-Brazil. Braz J Biol 75: 120-130.

GREENWOOD KL \& MCKENZIE BM. 2001. Grazing effects on soil physical properties and the consequences for pastures: a review. Aust J Exp Agric 41: 1231-1250.

GUIMARÃES DV, SILVA MLN, CURI N, MARTINS RP \& NETO JOM. 2019. Modeling of Soil Losses on a Yellow Argisol Under Planted Forest. Floresta Ambient 26: 1-11.

GUIMARÃES RZ, LINGNAU C, RIZZI NE, SCHEICHI RG \& BIANCHI RC. 2011. Espacializacao da perda de solo por erosao laminar na microbacia do Rio Campinas, Joinville SC. RAEGA 23: 534-554.

GURGEL RS, JÚNIOR OAC, GOMES RAT, GUIMARÃES RF, CÂMARA JFA \& SOBRINHO DA. 2011. Identification of vulnerable areas for erosion using the USLE model in the Riachão das Neves (BA) municipality. Geogr Ens Pesqui 15: 93-112.

HU L \& FLANAGAN DC. 2013. Towards new-generation soil erosion modeling: Building a unified omnivorous model. J Soil and Water Cons 68: 100-103.

IRVEM A, TOPALOGLU F \& UYGUR V. 2007. Estimating spatial distribution of soil loss over Seyhan River Basin in Turkey. J Hydrol 336: 30-37.

KREITLOW JP, SILVA JSV, NEVES SMAS, NEVES RJ \& NEVES LFS. 2016. Vulnerabilidade ambiental e conflito no uso da terra no município de Mirassol D'Oeste, Brasil. Rev Bras Cartogr 68: 1917-1936. 
LEOMO S, GINTING S, SABARUDDIN L \& TUFAILA M. 2016. Estimation of Esorion Hazard Level Using Universal Soil Loss Equation (USLE) Method in Endanga Watershed, Southeast Sulawesi, Indonesia. Adv Environ Biol 10: 101-106.

LIN BS, THOMAS K, CHEN CK \& HO HC. 2016. Evaluation of soil erosion risk for watershed management in Shenmu watershed, central Taiwan using USLE model parameters. Paddy Water Environ 14: 19-43.

LOPES FB, ANDRADE EM, TEIXEIRA AS, CAITANO RF \& CHAVES LCG. 2011. Applied geoprocessing for soil loss estimation in a Brazilian semiarid watershed. Revista Agro@mbiente On-line 5: 88-96.

MARTINS SG, SILVA MLNS, AVANZI JC, CURI N \& FONSECA S. 2010. Fator cobertura e manejo do solo e perdas de solo e água em cultivo de eucalipto e em mata atlântica nos tabulerios costeiros do estado do Espírito Santo. Sci For 38: 517-526.

MEDEIROS GOR, GIAROLLA A, SAMPAIO G \& MARINHO MA. 2016. Diagnosis of the accelerated soil erosion in São Paulo state (Brazil) by the soil lifetime index methodology. Rev Bras Cienc Solo 40: 1-15.

MEKONNEN M, KEESSTRA SD, STROOSNIJDER L, BAARTMAN JEM \& MAROULIS J. 2014. Soil conservation through sediment trapping: a review. Land Degrad Develop 26: 544-556.

MINELLA JPG, MERTEN GH, REICHERT JM \& SANTOS DR. 2007. Identificação e implicações para a conservação de solos das fontes de sedimentos em bacias hidrográficas. Rev Bras Cienc Solo 31: 1637-1646.

MINELLA JPG, MERTEN GH, WALLING DE \& REICHERT JM. 2009. Changing sediment yield as an indicator of improved soil management practices in southern Brazil. Catena 79: 228-236.

MMA - MINISTÉRIO DO MEIO AMBIENTE. 2016. Cartas de vegetação PROBIO (MMA). Brasília. http://mapas.mma. gov.br/mapas/aplic/probio/datadownload.htm?/.

MOORE ID \& BURCH GJ. 1986. Modeling erosion and deposition: Topographic effects. Transações da ASAE 29: 1624-1640.

MOSBAHI M, BENABDALLAH M \& BOUSSEMA RM. 2013. Assessment of soil erosion risk using SWAT model. Arab J Geosci 6: 4011-4019.

OLIVEIRA AH, SILVA MLN, CURI N, AVANZI JC, KLINKE G \& ARAÚJO EF. 2013. Water erosion in soils under eucalyptus forest as affected by development stages and management systems. Ciênc Agrotec 37: 159-169.
OLIVEIRA FG, SERAPHIM OJ \& BORJA MEL. 2015. Estimativa de Perdas de Soloe Do Potencial Natural de Erosão da Bacia de Contribuição da Microcentral Hidrelétrica do Lageado, Botucatu-SP. Energ Agric 30: 302-309.

PASQUATTO MC \& TOMAZONI JC. 2016. Estudo do processo erosivo laminar na bacia de captação do rio Barro Preto, em Coronel Vivida-PR. Rev Bras Geogr Fís 9: 555-570.

PHAM TG, DEGENER J \& KAPPAS M. 2018. Integrated universal soil loss equation (USLE) and geographical Information System (GIS) for soil erosion estimation in a Sap basin: Central Vietnam. Int Soil Water Conserv Res 6: 99-110.

PRADHAN B, CHAUDHARI A, ADINARAYANA I \& BUCHROITHNER MF. 2012. Soil erosion assessment and its correlation with landslide events using remote sensing data and GIS: a case study at Penang Island, Malaysia. Environ Monit Assess 184: 715-727.

REICHERT JM, RODRIGUES MF, PELÁEZ JJZ, LANZA R, MINELLA JPG, ARNOLD J \& CAVALCANTE RBL. 2017. Water balance in paired watersheds with eucalyptus and degraded grassland in Pampa biome. Agric For Meteorol 237: 282-295.

RIBEIRO LS. 2006. Análise Qualitativa e Quantitativa de Erosão Laminar no Município de Campos dos Goytacazes/ RJ através de técnicas de Geoprocessamento. Dissertação (Mestrado em Engenharia Civil) - Universidade Estadual do Norte Fluminense Darcy Ribeiro. Campos dos Goytacazes, 2006. (Unpublished).

RODRIGUES MF, REICHERT JM, MINELLA JPG, DALBIANCO L, LUDWIG RL, RAMON R, RODRIGUES LA \& BORGES JÚNIOR N. 2014. Hydrosedimentology of nest ed subtropical watershed swith native and eucalyptus forests. J Soils Sediments 14: $1311-1324$.

SANTOS HGD, JACOMINE PKT, ANJOS LHCD, OLIVEIRA VÁD, LUMBRERAS JF \& COELHO MR. 2013. Sistema Brasileiro de Classificação de Solos. 3a ed., Brasília. DF: Embrapa.

SCHICK J, BERTOL I, BARBOSA FT, MIQUELLUTI DJ \& COGO NP. 2017. Water erosion in a long-term soil management experiment with a Humic Cambisol. Rev Bras Cienc Solo 41: 1-13.

SCHMIDT S, TRESCH S \& MEUSBURGER K. 2019. Modification of the RUSLE slope length and steepness factor (LSfactor) based on rainfall experiments at steep alpine grasslands. MethodsX 6: 219-229.

SHABANI F, KUMAR L \& ESMAEILI A. 2014. Improvement to the prediction of the USLE K factor. Geomorphology 204 : 229-234.

SILVA BPC, SILVA MLN, BATISTA PVG, PONTES LM, ARAÚJO EF \& CURI N. 2016. Soil and water losses in eucalyptus plantation and natural forest and determination of the 
USLE factors at a pilot sub-basin in Rio Grande do Sul, Brazil. Ciênc Agrotec 40: 432-442.

SILVA DCC, ALBUQUERQUE FILHO JL, SALES JCA \& LOURENCO RW. 2017. Identification of Areas With Soil Loss Above the Tolerable Using NDVI for calculating the C Factor of USLE. Ra'e Ga 42: 72-85.

SILVA JV, ALECRIM MAB, SILVA DDO, COSTA CC \& OLIVEIRA RJ. 2010. Perdas de solo e água por erosão hídrica em floresta equiânea em um Latossolo Vermelho-Amarelo. Rev Bras Ciênc Agrár 5: 579-584.

SILVA MA, FREITAS DAF, SILVA MLN, OLIVEIRA AH, LIMA GC \& CURI N. 2013. Sistema de informações geográficas no planejamento de uso do solo. Rev Bras Ciênc Agrár 8: 316-323.

SILVA VCB \& MACHADO PS. 2014. SIG na Análise Ambiental: Susceptibilidade Erosiva da Bacia Hidrográfica do Córrego Mutuca, Nova Lima-Minas Gerais. Rev de Geog 31: 66-87.

SILVA VDA, MOREAU MS, MOREAU A \& REGO NA. 2011. USO da terra e perda de solo na Bacia Hidrográfica do Rio Colônia, Bahia. R Bras Eng Agríc Ambiental 15: 310-315.

SOUZA V \& GASPARETTO NVL. 2012. Application of the Universal Soil Loss Equation (USLE) at the Pinhalzinho segundo stream Basin in Parana State (Brazil) Northwest Region. Rev Bras Geomorf 13: 267-278.

STIPP NAF, MENDONÇA FA \& CAMPOS RA. 2011. O potencial de erosão de uma Bacia Hidrográfica: utilização da Equação Universal de Perda de Solo (EUPS) como Ferramente de Gestão Ambiental. Geografia (Londrina) 20: 29-51.

TESFAYE G, DEBEBE Y \& FIKIRIE K. 2018. Soil Erosion Risk Assessment Using GIS Based USLE Model for Soil and Water Conservation Planning in Somodo Watershed, South West Ethiopia. Int J Agric Environ Res 4: 35-43.

TOMAZONI JC, MANTOVANI LE, BITTEMCOURT AVL \& ROSA FILHO EF. 2005. A sistematização dos fatores da EUPS em Sig para quantificação da erosão laminar na bacia do rio Anta Gorda (PR). Estud Geogr 3: 01-21.

TUCHTENHAGEN IK, HARTWIG MP, NUNES MCM, LIMA CLR, SILVA TP \& NACHTIGALL SD. 2017. Estimativa da erosão hídrica por meio do modelo USLE na sub-bacia Santa Rita em Pelotas-RS. Rev Ibero-Am Ciênc 8: 88-96.

VOLK LBS \& COGO NP. 2014. Erosão hídrica, em três momentos da cultura do milho, influenciada por métodos de preparo do solo e semeadura. Rev Bras Cienc 38: 565-574.

WEBER E, HASENACK H \& FERREIRA CJS. 2016. Adaptação do modelo digital de elevação do SRTM para o sistema de referência oficial brasileiro e recorte por unidade da federação. Porto Alegre: UFRGS/Centro de Ecologia. https://www.ufrgs.br/labgeo.

WEILER EB, CRUZ JC, REICHERT JM, SANTOS FD, MANTOVANELLI BC, FANTINEL RA, TAMIOSSO MF \& BAUMHARDT E. 2019. USLE COMO ferramenta para planejamento de uso do solo: estudo de caso Bacia Cachoeira Cinco Veados, RS. In: Aguilera JG and Zuffo AM. A Preservação do Meio Ambiente e o Desenvolvimento Sustentável. Ponta Grossa, PR: Atena Editora 24: 249-262.

WISCHMEIER WH \& SMITH DD. 1978. Predicting rainfall erosion losses: a guide to conservation planning. Washington: USDA. (Agricultural Handbook; no. 537).

ZOLIN CA, FOLEGATTI MV, MINGOTI R, SÁNCHEZ-ROMÁN RM, PAULINO J \& GONZÁLES AMGO. 2011. Minimização da Erosão em Função do Tamanho e Localização das Áreas de Floresta no contexto co Programa "Conservador das Águas". Rev Bras Cienc Solo 35: 2157-2166.

ZOLA FP \& JUVENAL FM. 2016. Estudio de la erosión hídrica laminar de la tioc Del ayllu sikuya del município de Llallagua. Rev Ibero-Am Ciênc 7: 76-81.

\section{How to cite}

WEILER EB, TAMIOSSO MF, CRUZ JC, REICHERT JM, SCHORR LPB, MANTOVANELLI BC, DOS SANTOS FD, FANTINEL RA \& BAUMHARDT E. 2021. Integrated Environmental Management and Planning based on Soil Erosion Susceptibility Scenarios. An Acad Bras Cienc 93: e20191120. DOI 10.1590/0001-3765202120191120.

Manuscript received on September 17, 2019; accepted for publication on May 6, 2020

ELENICE B. WEILER ${ }^{1}$

https://orcid.gov/0000-0003-3389-4234

MARÍLIA F. TAMIOSSO ${ }^{2}$

https://orcid.gov/0000-0003-1590-0098

JUSSARA C. CRUZ

https://orcid.gov/0000-0002-0901-1254

JOSÉ MIGUEL REICHERT ${ }^{1}$

https://orcid.gov/0000-0001-9943-2898

LUIS PAULO B. SCHORR ${ }^{4}$

https://orcid.gov/0000-0002-0527-9114

BRUNO C. MANTOVANELLI ${ }^{1}$

https://orcid.gov/0000-0003-4291-1729

FERNANDA D. DOS SANTOS ${ }^{3}$

https://orcid.gov/0000-0002-6337-3061 


\section{ROBERTA A. FANTINEL ${ }^{1}$}

https://orcid.gov/0000-0002-1827-7943

\section{EDNER BAUMHARDT ${ }^{5}$}

https://orcid.gov/0000-0001-8480-4521

'Universidade Federal de Santa Maria/UFSM, Centro de Ciências Rurais, Campus Sede, Av. Roraima, 1000, Cidade Universitária, Camobi, 97105-900 Santa Maria, RS, Brazil

${ }^{2}$ Universidade Federal do Pampa/UNIPAMPA, Campus Alegrete, Av. Tiarajú, 810, Ibirapitã, 97546-550 Alegrete, RS, Brazil ${ }^{3}$ Universidade Federal de Santa Maria/UFSM, Centro de Tecnologia, Campus Sede, Av. Roraima, 1000, Cidade Universitária, Camobi, 97105-900 Santa Maria, RS, Brazil

${ }^{4}$ Universidade Federal de Lavras/UFLA, Departamento de Ciências Florestais, Campus Universitário, Caixa Postal 3037, 37200-000 Lavras, MG, Brazil

${ }^{5}$ Universidade Federal de Santa Maria/UFSM, Departamento de Engenharia Florestal, Campus Frederico Westphalen, Linha 7 de Setembro, BR 386, Km 40, s/n, Vista Alegre, 98400-000 Frederico Westphalen, RS, Brazil

Correspondence to: Elenice Broetto Weiler

E-mail:elenicebroettoweiler@gmail.com

\section{Author contributions}

Elenice B. Weiler was responsible for the implementation of the methodology, literature review, generation and analysis of results, and writing the first draft. Marilia F. Tamiosso, Bruno C. Mantovanelli and Fernanda D. dos Santos helped with data collection and organization. Marilia F. Tamiosso and Jussara C. Cruz contributed substantially to data analysis and interpretation. José Miguel Reichert and Edner Baumhardt critically reviewed the article, establishing relevant intellectual content. Bruno C. Mantovanelli, Fernanda D. dos Santos, Roberta A. Fantinel contributed for the preparation of the manuscript and final formatting. Luis Paulo B. Schorr was responsible for the translation into English. All authors approved the final version to be published.

\section{(c) BY}

